\title{
Analysis of Metal in Wastewater Collected from Three Pharmaceutical Industries Located in Tongi Area of Gazipur District
}

\author{
Shakibul Islam ${ }^{\mathrm{a}}$, A. K. M. Rashidul Alam ${ }^{\mathrm{a}}$ and Shahidul Islam ${ }^{\mathrm{b} *}$ \\ ${ }^{a}$ Department of Environmental sciences, Jahangirnagar University, Savar, Dhaka - 1342 and bAnalytical \\ Research Division, BCSIR Laboratories, Dhaka, Bangladesh.
}

\begin{abstract}
Wastewater qualities of three pharmaceutical industries were determined during July 2005 to January 2006. Alkaline earth metals including calcium (Ca) and magnesium (Mg) of wastewater ranged 41.79-54.5mgL $\mathrm{m}^{-1}$ and 10.5996-32.2926 mgL ${ }^{-1}$, respectively. Alkali metals including potassium $(\mathrm{K})$ and sodium $(\mathrm{Na})$ of wastewater ranged 3.44-18.98 $\mathrm{mgL}^{-1}$ and $67.57-128.71 \mathrm{mgL}^{-1}$, respectively. Transition metal iron (Fe) ranged 1.02-2.13 $\mathrm{mgL}^{-1}$. On an average metals including zinc $(\mathrm{Zn})$, lead (Pb), nickel (Ni) and cadmium (Cd) were in trace amount i.e. $84.32 \mu \mathrm{gL}^{-1}, 11.59 \mu \mathrm{gL}-1,4.96 \mu \mathrm{gL}^{-1}$ and $0.1047 \mu \mathrm{gL}^{-1}$, respectively in the wastewater. Copper $(\mathrm{Cu})$ was undetected in wastewater. The average amount of iron of site $\mathrm{N}$, magnesium of site $\mathrm{S}$ and potassium of site $\mathrm{B}$ of wastewater were higher than that of the standard of Department of Environment (DoE) of Bangladesh.
\end{abstract}

Key words: Metals, Pharmaceutical wastewater, DoE standards.

\section{Introduction}

Water pollution in Bangladesh is increasing at an alarming rate. The Department of Environment has identified 450 polluting industrial units in Dhaka Division. Most of these are located in Dhaka and neighboring Gazipur and Narayanganj districts. From these 450 industries only 21 industries have taken clearance from the Department of Environment. Discharges from these industries badly affect the nearby aquatic environment (Gain, 1998). Industries and factories at Tongi near Dhaka regularly dump solid waste and liquid effluent in Turag River. Color of water of Turag is dark and has a strong odor. At least 20 factories are responsible for polluting Turag. The industrial units include textiles mills and pharmaceutical plants, etc. There are about 100 private and 2 public pharmaceutical industries discharging $3500 \mathrm{~m}^{3}$ /day waste water where the pollution load is $700 \mathrm{~kg} /$ day (Bangladesh National Report, 1996-2001).

Large qualities of water are usually used in any industries' production either as raw material, or in process control, or for both. A small quantity of water is absorbed and the rest comes out as waste. These wastes contain various contaminants, which are discharged directly into the surface water with or without any treatment. The dumping of effluents into an aquatic body can seriously affect its flora, fauna and abi otic components. The major effects of toxic discharges on aquatic fauna and water quality are death of fish and contamination of water by heavy metals (Goutam et al., 1992). In the present research wastewaters collected from three pharmaceutical industries located in Tongi were analyzed for metals present.

\section{Materials and Methods}

\section{Site selection and description}

Three sites were selected as point sources of pollution i.e. BEXIMCO, SK+F (ESKAYEF) and NOVARTIS Pharmaceuticals that are abbreviated as $\mathrm{B}, \mathrm{S}$ and $\mathrm{N}$, respectively. The selected sites are located in Kathalia, Tongi Paurashava, Gazipur Sadar Thana, Gazipur. From these industries effluents are directly discharged into nearby Turag river through a drainage system.

\section{Duration of sampling}

The sampling was carried out from July 2005 to January 2006 at one month interval maintaining routine monitoring. A fixed collection time i.e. 8:30 am to 9:00 am was maintained during the study period.

\footnotetext{
* Corresponding author: E-mail: sislama@hotmail.com.
} 


\section{Sample analysis methods}

Sodium and potassium were determined by flame photometer (JENWAY PFP7, Wagtech. Co., UK). Iron, calcium, magnesium, lead, cadmium, zinc, copper and nickel were determined by atomic absorption spectrophotometer (AAS) (SHIMADZU, Model-AA-6401F, Japan). At first, acid treatment was carried out for collected wastewater samples i.e. the samples were treated with dilute nitric acid $\left(\mathrm{HNO}_{3}\right)$ to adjust $\mathrm{pH}$ at 2.0 (approximately) and filtered. Then samples were determined by AAS.

\section{Results and Discussion}

Iron (Fe), calcium (Ca), magnesium (Mg), potassium (K), sodium (Na), zinc ( $\mathrm{Zn}$ ) and nickel (Ni) are used for making multivitamin capsule and other purpose in pharmaceuticals (Shahidi, 2002).

The concentration of metals in wastewater from July 2005 to January 2006 at sites B, S and N are shown in Fig. 1. The data indicates that for site $\mathrm{B}, \mathrm{S}$ and $\mathrm{N}$, the maximum concentration of iron was 4.12, 2.734 and $4.862 \mathrm{mgL}^{-1}$ during January 2006, respectively and the minimum was 0.527 $\mathrm{mgL}^{-1}$ during September, $0.373 \mathrm{mgL}^{-1}$ during September (site $\mathrm{N}$ ), and $0.815 \mathrm{mgL}^{-1}$ during August 2005, respectively (Fig. 1a). The concentration of iron gradually increased during October, November, December and January at all sites. The average concentration of iron for sites $\mathrm{B}, \mathrm{S}$ and $\mathrm{N}$ were $1.73,1.02$ and $2.13 \mathrm{mg} \mathrm{L}^{-1}$, respectively. The total average of iron for three sites during the study period was $1.63 \mathrm{mg} / \mathrm{l}$ which was below the Department of Environment (DoE) standard (2.0 $\mathrm{mgL}^{-1}$ ) (DoE, 2003). The concentration of iron in site N (2.13 mgL-1) was slightly higher than the DoE standard (DoE, 2003).

The maximum amount of calcium at sites of $\mathrm{B}, \mathrm{S}$ and $\mathrm{N}$ were found 64.98, 124.275 and $101.7 \mathrm{mg} \mathrm{L}^{-1}$ during January 2006, respectively and the minimum was 24.88, 22.175 and 34.26 mg $\mathrm{L}^{-1}$ during September 2005, respectively (Fig. 1b). Concentration of $\mathrm{Ca}$ gradually increased during October, November, December and January at all sites. The average of calcium for site B, S and N were 41.79, 49.43 and 54.57 $\mathrm{mgL}^{-1}$, respectively. Total average of calcium for three sites during the study period was $48.60 \mathrm{mgL}^{-1}$ below the DoE standard (75.0 mgL-1) (DoE, 2003).
Fig. 1c shows that at site B, S and N, maximum amount of magnesium were found 29.02, 82.45 and $14.9075 \mathrm{mgL}^{-1}$ during January 2006, respectively and the minimum was 12.24 , 9.875 and $5.23 \mathrm{mgL}^{-1}$ during September 2005, respectively. Magnesium gradually increased during October, November, December and January at all sites. The average concentration of magnesium at site B, S and $\mathrm{N}$ was 21.01, 32.2926 and $10.5996 \mathrm{mgL}^{-1}$, respectively. Total average of magnesium at three sites during the study period was $21.30 \mathrm{mgL}^{-1}$ below the DoE standard (30 $\mathrm{mgL}^{-1}$ ) (DoE, 2003) but the concentration of magnesium in site $\mathrm{S}\left(32.2926 \mathrm{mgL}^{-1}\right)$ was higher than the DoE standard (DoE, 2003).

The maximum concentration of sodium at sites $\mathrm{B}, \mathrm{S}$ and $\mathrm{N}$ were found 306, 118 and $370 \mathrm{mg} \mathrm{L}^{-1}$ during January 2006, respectively and the minimum was $67,38.50$ and $38 \mathrm{mgL}^{-1}$ during September 2005, respectively (Fig. 1d). Sodium gradually increased during October, November, December and January at all sites. The average concentration of sodium for site $\mathrm{B}, \mathrm{S}$ and $\mathrm{N}$ was $128.71,67.57$ and $113.71 \mathrm{mgL}^{-1}$, respectively. Total average of sodium for these three sites during the study period was $103.33 \mathrm{mgL}^{-1}$ below the DoE (2003) standard (200 $\mathrm{mg} \mathrm{L}^{-1}$ ) (DoE, 2003).

The maximum concentration of potassium was found 25.0, 24.3 and $6.0 \mathrm{mgL}^{-1}$ during January 2006 and the minimum was 14.2, 2.26 and $1.91 \mathrm{mgL}^{-1}$ during September 2005 in site $\mathrm{B}, \mathrm{S}$ and $\mathrm{N}$, respectively (Fig. 1e). Potassium gradually increased during October, November, December and January at all sites. The average amount of potassium for site $B, S$ and $\mathrm{N}$ was $18.98,9.53$ and $3.44 \mathrm{mgL}^{-1}$, respectively. Total average of potassium for three sites during the study period was $10.65 \mathrm{mg} / \mathrm{l}$ below the DoE standard (12.0 $\left.\mathrm{mgL}^{-1}\right)$ but the average amount of potassium in site $\mathrm{B}\left(18.98 \mathrm{mgL}^{-1}\right)$ was higher than the DoE standard (DoE, 2003).

The maximum concentration of lead was found 13.611, 9.075 and 63.207 $\mu \mathrm{gL}^{-1}$ during January 2006, respectively and the minimum was 2.89, 3.91 and $5.77 \mu \mathrm{gL}^{-1}$ during September, 2005 in site B, S and N, respectively (Fig. 1f). Lead gradually increased during October, November, December and January at all sites. The average amount of lead for site $\mathrm{B}, \mathrm{S}$ and $\mathrm{N}$ was $6.65,5.87$ and $25.25 \mu \mathrm{gL}^{-1}$, respectively. Total average of lead for three pharmaceutical waste water disposal sites during the study period was 12.59 $\mu \mathrm{gL}^{-1}$ and below the DoE standard (0.1 $\mathrm{mgL}^{-1}$ ) (DoE, 2003). 

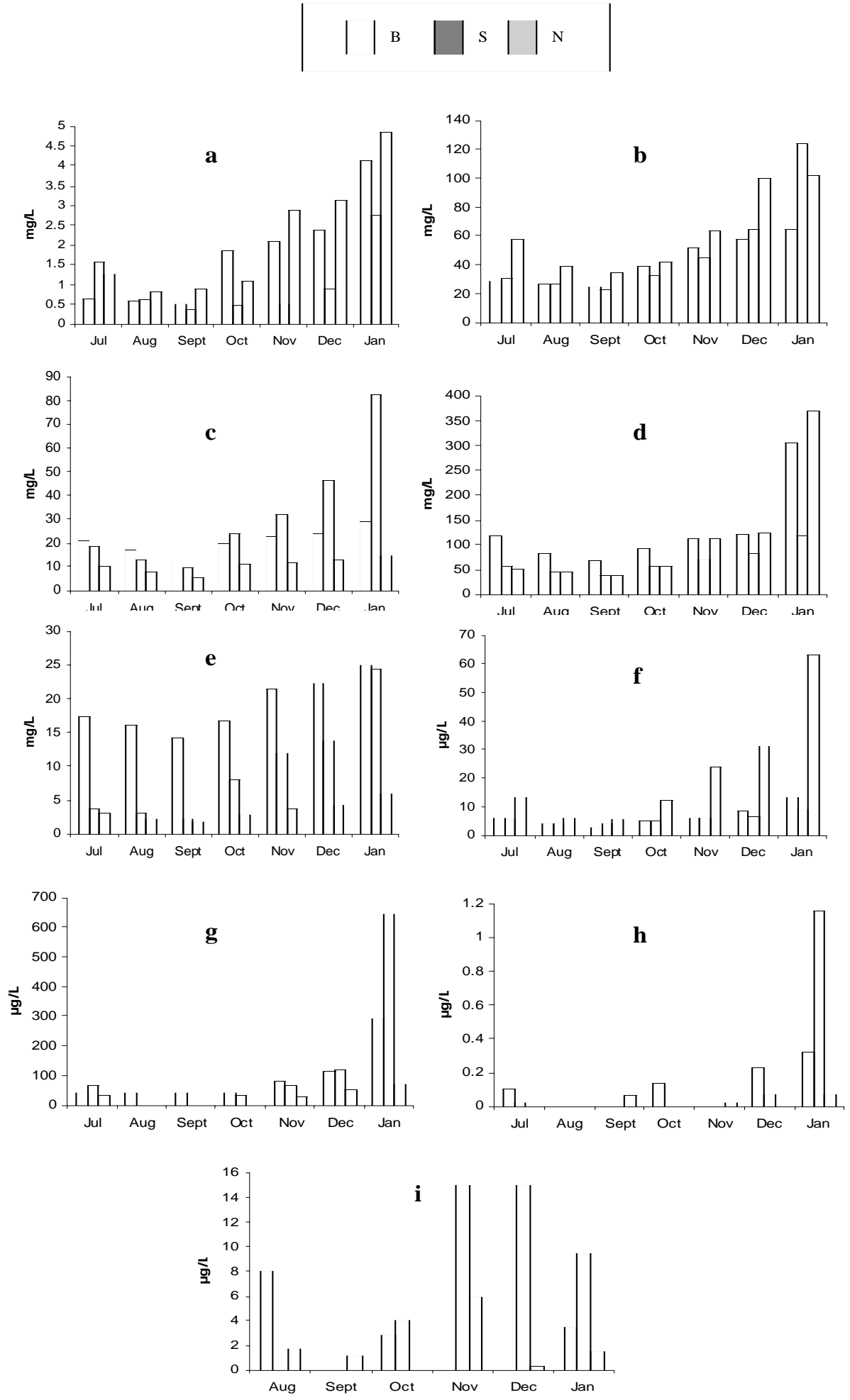

Fig. 1. Status of metals of wastewater over the study period from July 2005 to January 2006 in the sites of B, S and $\mathrm{N},(\mathrm{a}=$ Iron, $\mathrm{b}=$ Calcium, $\mathrm{c}=$ Magnesium, $\mathrm{d}=$ Sodium, $\mathrm{e}=$ Potassium, $\mathrm{f}=$ Lead, $\mathrm{g}=\mathrm{Zinc}, \mathrm{h}=$ Cadmium and $\mathrm{i}=$ Nickel; $B$ = Beximco; S = SK+ F and N = Novartis Pharmaceuticals)

\section{Enzyme Activity (Unit/ml) Enzyme Activity (Unit/ml)}


Fig. 1g shows that in site $\mathrm{B}, \mathrm{S}$ and $\mathrm{N}$, the maximum concentration of Zinc was found 294.938, 648.137 and 68.5875 $\mu \mathrm{gL}^{-1}$ during January 2006, respectively and the minimum was $38.325 \mu \mathrm{gL}^{-1}$ during October 2005 for site B and trace amount of Zinc was found during August and September, 2005 for site S and N. Zinc gradually increased during November, December and January at all sites. The average amount of Zinc for site B, S and N was 93.48, 133.26 and $26.11 \mu \mathrm{gL}^{-1}$, respectively. Total average of Zinc for three pharmaceutical waste water disposal sites during the study period was $84.32 \mu \mathrm{gL}^{-1}$ and below the DoE standard (5.0 $\mathrm{mgL}^{-1}$ ) (DoE, 2003).

In sites of $\mathrm{B}, \mathrm{S}$ and $\mathrm{N}$, the maximum concentration of cadmium was found $0.32,1.1584$ and $0.07 \mu \mathrm{gL}^{-1}$ during January 2006, respectively and cadmium was undetected for all sites during August 2005 (Fig. 1h). The average amount of cadmium for site B, S and $\mathrm{N}$ was $0.1143,0.1785$ and $0.05 \mu \mathrm{gL}^{-1}$, respectively. The total average of cadmium for these three pharmaceutical waste water disposal sites during the study period was $0.1047 \mu \mathrm{gL}^{-1}$ and below the DoE standard (0.05 $\mathrm{mgL}^{-1}$ ) (DoE, 2003).

In the present research, in site $\mathrm{B}, \mathrm{S}$ and $\mathrm{N}$, the maximum concentration of nickel was found $12 \mu \mathrm{gL}^{-1}$ during January 2006; $23 \mu \mathrm{gL}^{-1}$ during July 2005 and $1.7 \mu \mathrm{gL}^{-1}$ during August 2005, respectively and nickel was undetected for site $\mathrm{B}$ and S during September 2005 and $1.1 \mu \mathrm{gL} \mathrm{L}^{-1}$ for site N during September 2005 (Fig. 1i). The average value of nickel in all sites was $4.83 \mu \mathrm{gL}^{-1}$ below the DoE standard $\left(1.0 \mathrm{mgL}^{-1}\right)$ (DoE, 2003).

Copper was totally undetected in waste water of three pharmaceuticals during the study period. Relevantly, this AAS (SHIMADZU, Model-AA-6401F, Japan) was procured in BCSIR in 1996. However the actual lowest detection limit for copper has not been detected in this model still now.

From present findings it is most important that iron, calcium, magnesium, potassium, sodium, lead and zinc gradually increased from October to January in all sites. These may rise as in rainy season all of the parameters decreased due to being diluted by huge amount of water in the effluent drain and on the other hand in dry season (November-January) excess rain water was being decreased by evaporation and thus the concentration of the parameters were being increased in effluent drain.
It is also observed that metals varied in concentration from site to site during the study period. For example, the maximum concentration of $\mathrm{Fe}, \mathrm{Na}$ and $\mathrm{Pb}$ were found (November-January) at site $\mathrm{N}$ than other two sites of $\mathrm{B}$ and $\mathrm{S}$. The sequence of concentration of $\mathrm{Fe}, \mathrm{Na}$ and $\mathrm{Pb}$ is site $\mathrm{N}>$ site $\mathrm{B}>$ site $\mathrm{S}$. The reason may be Novartis pharmaceuticals (site $\mathrm{N}$ ) can use these metals as production material in more amounts in order to make the multivitamin capsule and other purposes than other two pharmaceuticals during that time. In addition, the sequence of maximum concentration of $\mathrm{Mg}$ and $\mathrm{K}$ is site $\mathrm{S}>$ site $\mathrm{B}>$ site $\mathrm{N}$ and site $\mathrm{B}>$ site $\mathrm{S}>$ site $\mathrm{N}$, respectively during October to January.

We can also find that metals (Fe, $\mathrm{Ca}, \mathrm{Mg}, \mathrm{K}$ and $\mathrm{Na}$ ) are found in huge amount as they are essential elements for human body. The pharmaceutical industries use these metals in amount for making multivitamin capsule and other purpose. Other metals ( $\mathrm{Zn}, \mathrm{Cd}, \mathrm{Ni}$ and $\mathrm{Pb}$ ) are found in trace amount since they are needed as trace element for human body. So the pharmaceutical industries use these metals in fewer amounts in the products (Shahidi, 2002).

Regerand et al (2005) observed that supply of iron into water significantly increases the mortality of ecdyonurus joernensis. The survival of aquatic organisms in solutions of salts of iron or other metals in natural water containing humic substances was found to be lower than in artificially made clear water. In this study, the average amount of iron at site $\mathrm{N}\left(2.13 \mathrm{mg} \mathrm{L}^{-1}\right)$ was slightly higher than the DoE standard (DoE, 2003). Besides the amount of iron for sites B and $\mathrm{N}$ during November-January and for all sites during January exceeds the DoE standard (DoE, 2003). So this high amount of iron was certainly harmful for aquatic habitats of Turag river, Tongi.

Present study shows that the concentration of calcium for sites $\mathrm{B}$ and $\mathrm{N}$ during January exceeds the DoE standard (DoE, 2003). The average amount of magnesium of site $S$ (32.2926 $\mathrm{mgL}^{-1}$ ) was higher than the DoE standard (DoE, 2003). The average concentration of potassium of site $B$ (18.98 $\mathrm{mgL}^{-1}$ ) was higher than the DoE standard (DoE, 2003). Moreover the amount of potassium for sites $B$ and $S$ during December-January exceeds the DoE standard (DoE, 2003). The amount of sodium for sites $B$ and $N$ during January exceeds the DoE standard (DoE, 2003). Remarkably calcium, magnesium, potassium, and sodium gradually 
Islam, Alam and Islam

Table I. Comparison of metals of site B, S and N during July 2005 to January 2006 with DoE (2003).

\begin{tabular}{c|c|cc|c|c|c|c|c|c|c}
\hline & \multicolumn{10}{|c}{ PARAMETER } \\
\hline SITE & $\mathrm{Fe} \mathrm{mgL}^{-1}$ & $\mathrm{Ca}$ & $\mathrm{mgL}^{-1}$ & $\mathrm{Mg} \mathrm{mgL}^{-1}$ & $\mathrm{~K} \mathrm{mgL}^{-1}$ & $\mathrm{Na} \mathrm{mgL}^{-1}$ & $\mathrm{~Pb} \mu \mathrm{mg}^{-1}$ & $\mathrm{Cd} \mu \mathrm{mLL}^{-1}$ & ${\mathrm{Zn} \mu \mathrm{mgL}^{-1}}^{\mathrm{Ni} \mu \mathrm{mgL}^{-1}}$ & $\mathrm{Cu} \mathrm{mgL}^{-1}$ \\
\hline $\mathrm{B}$ & 1.73 & 41.8 & 21.0 & 19.0 & 6.56 & 93.5 & 0.11 & 93.5 & 4.7 & $\mathrm{ND}$ \\
$\mathrm{S}$ & 1.02 & 49.4 & 32.3 & 9.53 & 67.6 & 5.87 & 0.18 & 133 & 4.2 & $\mathrm{ND}$ \\
$\mathrm{N}$ & 2.13 & 54.5 & 10.6 & 3.44 & 114 & 25.2 & 0.11 & 26.1 & 1.3 & $\mathrm{ND}$ \\
$\mathrm{DoE}$ & 2.00 & 75.0 & 30.0 & 12.0 & 200 & $0.10 \mathrm{mg}$ & $0.05 \mathrm{mg}$ & $5.0 \mathrm{mg}$ & $1.0 \mathrm{mg}$ & $1.0 \mathrm{mg}$ \\
\hline
\end{tabular}

Table II. Comparison of total average amount of metals of site B, S and N (B+S+N/3) during July 2005 to January 2006 with DoE (2003).

\begin{tabular}{|c|c|c|c|c|c|c|c|c|c|}
\hline \multicolumn{10}{|c|}{$\begin{array}{l}\text { PARAMETER } \\
\end{array}$} \\
\hline SITE & FemgL $^{-1}$ & CamgL $^{-1}$ & $\mathrm{Mg} \mathrm{mgL}^{-1}$ & $\mathrm{KmgL}^{-1}$ & NamgL $^{-1}$ & ${\mathrm{~Pb} \mu g L^{-1}}^{-1}$ & $\mathrm{Cd} \mu g L^{-1}$ & $Z_{n} \mu g L^{-1}$ & NimgL $^{-1}$ \\
\hline AVG.OF TOTAL1.63 & 48.6 & 21.3 & 10.6 & 103 & 12.6 & 0.11 & 84.3 & 4.83 & \\
\hline DoE & 2.00 & 75.0 & 30.0 & 12.0 & 200 & $0.10 \mathrm{mg} / \mathrm{l}$ & $0.05 \mathrm{mg} / \mathrm{l}$ & $5.00 \mathrm{mg} / 11.00$ & $\mathrm{mg} / \mathrm{l}$ \\
\hline
\end{tabular}

increased during October, November, December and January in all sites. According to (Abel, 1996), the major cations and anions making up salinity are sodium, calcium, magnesium,and potassium and this excess salinity is toxic for fish in water habitat. So, these significant amounts of magnesium, potassium and sodium were sometimes toxic to the aquatic habitats of Turag river.

Present findings showed that lead gradually increased during October, November, December and January in all sites and total average of lead for three pharmaceutical waste water disposal sites during the study period was 12.59 ?g/l and below the DoE standard (0.1 mg/l) (DoE, 2003) did not show it as a effective pollutant in surrounding water bodies.

Total average of zinc, cadmium and nickel for three pharmaceutical waste water disposal sites during the study period were $84.32 \mu \mathrm{gL}^{-1}, 0.1047 \mu \mathrm{gL}^{-1}$ and $4.83 \mu \mathrm{gL}^{-1}$, respectively and was below the DoE standard $\left(5.0 \mathrm{mgL}^{-1}\right)$ for zinc, $(0.05 \mathrm{mg} / \mathrm{l})$ for cadmium and $\left(1.0 \mathrm{mgL}^{-1}\right)$ for nickel, respectively (DoE, 2003). Copper was totally undetected in waste water of three pharmaceuticals during the study period. So, the lower concentration of zinc, cadmium and nickel are not so harmful for aquatic habitats of Turag river.

\section{Conclusion}

The average concentration of iron at site $\mathrm{N}$, magnesium at site $\mathrm{S}$ and potassium at site $\mathrm{B}$, respectively of wastewater are higher than recommended by the Department of Environment (DoE) of Bangladesh. In dry season especially in January $\mathrm{Fe}, \mathrm{Ca}, \mathrm{Mg}, \mathrm{K}$ and $\mathrm{Na}$ for all sites (with few exceptions) exceed the DoE standard (DoE, 2003). Remarkably Fe, Ca, Mg, K, Na and Pb gradually increased during October, November, December and January and Zn gradually increased during dry season (November, December and January) at all sites. From the present investigation, it was found that pharmaceutical industries discharged a certain amount of effluents having metals which are dangerous in dry season for surrounding aquatic environment. It is urgently needed to treat the wastewater precisely for reducing toxic effect of metals on surrounding aquatic environment. Further investigation is needed to determine the effect of metals in pharmaceutical wastewater on microorganisms in control environment for sustainable management of wastewater.

\section{References}

Abel, P. D. (1996) Water Pollution Biology. 2nd Ed. (Taylor \& Francis Ltd., London) pp-133.

Bangladesh National Report. (1996-2001) Progress of implementation of the Habitat Agenda.

DoE (Department of Environment), (2003) A Compilation of environmental laws of Bangladesh. 
Gain P. (1998) Industrialization and Industrial pollution, BangladeshEnvironment: Facing the 21st Century. (SEHD, Dhaka) pp 164-185.

Goutam A., Joshi V. P. and Semwal O. P. (1992) Industrial effluent and aquatic pollution in Aquatic Environment. (Ashish Publishing House, New Delhi) pp 48-57.
Regerand T. I., Nefedova Z. A., Nemova N. N., Ruokolainen T. R., Toivonen L. V., Dubrovina L. V., Vuori K. M. and Markova, L. V. (2005) Effect of aluminum and iron on lipid metabolism in aquatic invertebrates. Journal of Applied Biochemistry and Microbiology., 41 (2): 192-198.

Shahidi, R. (2002) Quick Index of medical products \& problems, QIMP-11. (Katabon Central Mosque Campus, Dhaka).

Received : May 19, 2009;

Accepted : December 27, 2009 